\title{
Modeling photocatalytic degradation of diazinon from aqueous solutions and effluent toxicity risk assessment using Escherichia coli LMG 15862
}

\author{
Ali Toolabi ${ }^{1}$, Mohammad Malakootian ${ }^{2,3}$, Mohammad Taghi Ghaneian ${ }^{\text {* }}$, Ali Esrafili ${ }^{4}$, \\ Mohammad Hassan Ehrampoush' ${ }^{1}$, Mohsen AskarShahi ${ }^{5}$ and Maesome Tabatabaei ${ }^{6}$
}

\begin{abstract}
In this study, modeling and degradation of diazinon from contaminated water by advanced oxidation process together with a new test for effluent bioassay using E. coli were investigated. The experiments were designed based on response surface methodology. Nanoparticles (NPs) were synthesized using the sol-gel method. The shape characteristics and specifications of elements in the nanoparticles were characterized using scanning electron microscope and energy dispersive $X$-ray, respectively. Diazinon was measured using high performance liquid chromatography device and by-products due to its decomposition were identified by gas chromatography-mass (GC-MS). In the present study, effluent bioassay tests were conducted by defining the rate of dehydrogenase enzyme reducing alamar blue method. According to statistical analyses $\left(R^{2}=0.986\right)$, the optimized values for $\mathrm{pH}$, dose of NPs, and contact time were found to be $6.75,775 \mathrm{mg} / \mathrm{L}$, and $65 \mathrm{~min}$, respectively. At these conditions, $96.06 \%$ of the diazinon was removed. Four main by-products, diazoxon, 7-methyl-3-octyne, 2-isopropyl-6-methyl-4pyrimidinol and diethyl phosphonate were detected. According to the alamar blue reducing (ABR) test, 50\% effective concentration, no observed effect concentration, and 100\% effective concentration $\left(\mathrm{EC}_{100}\right)$ for the mortality rate of E. coli were obtained as 2.275, 0.839, and $4.430 \mathrm{mg} / \mathrm{L}$, respectively. Based on the results obtained, it was found that mentioned process was high efficiency in removing diazinon, and also a significant relationship between toxicity assessment tests were obtained $(P<0.05)$.
\end{abstract}

Keywords: Modeling, Diazinon, Dehydrogenase enzyme, Effluent bioassay

\section{Introduction}

Organophosphate pesticides (OPs) are among the largest and most diverse types of available pesticides. Considering that they affect a wide range of insects and rodents, these pesticides are used by farmers more than other types. But due to the lack of familiarity with the damaging effects of these toxins or proper principles of combating pests, most consumers do this job either incompletely or indiscriminately (Fadaei et al. 2012; Li et al. 2015;

\footnotetext{
*Correspondence: mtghaneian@yahoo.com

${ }^{1}$ Environmental Science and Technology Research Center, Department of Environmental Health Engineering, Shahid Sadoughi University of Medical Sciences, Yazd, Iran

Full list of author information is available at the end of the article
}

Maddah and Hasanzadeh 2017). Therefore, intentional or unintentional human exposure is as a result of the use of pesticides or their residuals in environments including air, water, soil, and plants. Considering global statistics, the largest portion of mortality from pesticides is related to these toxins. Diazinon is an organophosphate pesticides with $\mathrm{pKa}=2.6$ and medium risk (Kalantary et al. 2014). The major effects of diazinon on vertebrate life are inhibition of acetyl cholinesterase, resulting in aggregation of acetylcholine in acetylcholine receiver and hyper excitation of nerves and muscles. So far, various technologies have widely been applied for removal of diazinon in aqueous solution such as adsorption, electrocoagulation 
and biodegradation (Amooey et al. 2014; Ehrampoush et al. 2017).

Since conventional water and wastewater treatment processes are not very effective on the degradation of diazinon (Amooey et al. 2014; Kalantary et al. 2014; Ehrampoush et al. 2017), Recently, advanced oxidation process such as $\mathrm{UV} / \mathrm{H}_{2} \mathrm{O}_{2}, \mathrm{H}_{2} \mathrm{O}_{2} / \mathrm{Fe}^{2+}, \mathrm{NP}_{\mathrm{S}} / \mathrm{UV}$ and etc., due to high efficiency, low cost, and non-toxicity have been considered. $\mathrm{Li}$ et al. used $\mathrm{UV}$ and $\mathrm{UV} / \mathrm{H}_{2} \mathrm{O}_{2}$ process for the removal of diazinon from water resources (Li et al. 2015). Also, Kalantary et al. successfully used $\mathrm{TiO}_{2} / \mathrm{UV}$ process for the degradation of diazinon (Kalantary et al. 2014). $\mathrm{TiO}_{2}$ nanoparticles along with UV, have been considered as an effective method for water treatment (Amooey et al. 2014; Li et al. 2015; Ribeiro et al. 2015; Ehrampoush et al. 2017; Maddah and Hasanzadeh 2017). The energy of light from UV rays in contact with titanium atoms, stimulates its surface electrons and moves them from the valence layer to the conductive layer, The result of this energy change will be the formation of a halo at the surface of the titanium atom and the formation of free electrons $\left(\mathrm{OH}^{*}\right)$. These active radicals cause oxidation of organic matter in the solution and convert it to water and carbon dioxide. One of the disadvantages of titanium nanocatalysts is the existence of an inter-structural hole in this composition. This means that a less energy band of ultraviolet radiation will remain on the surface of the catalyst (Mohammadi and Sabbaghi 2014; Tian et al. 2014; Toolabi et al. 2017; Wang and Shih 2016). Accordingly, in the current study, to enhance the optimal response of titanium dioxide, silica dioxide was introduced to the reaction. Performing the effluent toxicity risk assessment after water treatment processes is essential for environmental, drinking water and public health. Previously, to determine the effluents toxicity, some methods such as tetrazolium salt, crystal violet, and colony forming unit were used. But often they were expensive, long-term, and unreliable (Pettit et al. 2005; Satyanarayan et al. 2016). Recently, alamar blue (AB) due to its high sensitivity and non-toxicity has been widely used in studies on bioassay in a biological range such as bacteria, piscine cells and planktonic assays (Rampersad 2012; Khalifa et al. 2013; Teh et al. 2017).

Because the oxidation-reduction potential (ORP) of alamar blue is more than the enzyme dehydrogenase, it was reduced by the dehydrogenase enzyme. But in the presence of living bacteria, alamar blue is converted to resorufin and the color of the solution changes from blue to pink (Nasiry et al. 2007; Rampersad 2012; Gregoraszczuk et al. 2015; Balouiri et al. 2016; Tyc et al. 2016; Zare et al. 2016; Teh et al. 2017; Toolabi et al. 2017). To achieve the best and most effective method of removal and risk assessment of diazinon in aqueous solution, more studies need to be done in this regard. Therefore, in this study, application of $\mathrm{Fe}_{3} \mathrm{O}_{4} / \mathrm{SiO}_{2} / \mathrm{TiO}_{2} / \mathrm{H}_{2} \mathrm{O}_{2} / \mathrm{UV}$-C process for the degradation of diazinon and novel test for the effluent toxicity risk assessment using Escherichia coli were conducted.

\section{Materials and methods \\ Chemicals and media}

Analytical diazinon pesticide with a purity of $98.5 \%$, Acetic acid 99.9\%, ethanol 99.9\%, chloride iron (II), chloride iron (III), tetra ethyl ortho silicate 95\%, tetra-n-butyl lorthotitanate, ammonium solution, alamar blue powder, agar muller hinton, broth nutrient, dimethyl sulfur oxide (DMSO), n-amyl alcohol, $\mathrm{HCl}$-phthalate buffer, glucose, sodium acetate, sodium bicarbonate, Sulfuric acid $98 \%$, Sodium Hydroxide 98\%, potassium phosphate monobasic and Dipotassium phosphate were purchased from Sigma Aldrich Co. The properties of diazinon and alamar blue are shown in Table 1.

\section{Microorganism}

A standard strain of Escherichia coli LMG 15862 bacteria was purchased from Tehran Razi Institute and immediately was stored at a temperature of $8{ }^{\circ} \mathrm{C}$.

\section{Synthesis of nanoparticles}

There are various methods for synthesizing and doping $\mathrm{TiO}_{2} / \mathrm{Fe}_{3} \mathrm{O}_{4} / \mathrm{SiO}_{2}$ nanoparticles. These routes include sol-gel process, co-precipitation, hydrothermal method, pyrolysis spray, sono-chemical synthesis, and wet immersion method (Tian et al. 2014; Gupta et al. 2015).

\section{$\mathrm{Fe}_{3} \mathrm{O}_{4}$ nanoparticles}

The synthesis of $\mathrm{Fe}_{3} \mathrm{O}_{4}$ nanoparticles was done according to co-precipitation method. Briefly, $23.36 \mathrm{~g}$ of chloride iron (III) and $8.62 \mathrm{~g}$ of chloride iron (II) were dissolved in $250 \mathrm{cc}$ of deionized water for $50 \mathrm{~min}$ and mixed at $87^{\circ} \mathrm{C}$ inside a reactor (Cylindrical and quartz glass with a diameter of $35 \mathrm{~cm}$ and length of $45 \mathrm{~cm}$ ). Thereafter, the resulting solution was slowly injected into $3.6 \mathrm{~L}$ of deionized water. Next, action bubbling of nitrogen gas was conducted for $24 \mathrm{~h}$ at $75^{\circ} \mathrm{C}$. After these three stages of washing with water and ethanol, $\mathrm{Fe}_{3} \mathrm{O}_{4}$ nanoparticles were formed (Shunxing et al. 2016; Maddah and Hasanzadeh 2017; Toolabi et al. 2017).

\section{$\mathrm{Fe}_{3} \mathrm{O}_{4} / \mathrm{SiO}_{2} / \mathrm{TiO}_{2}$ nanoparticles}

The synthesis of nanoparticles was done using the solgel method. The nanoparticles obtained in the previous step were dissolved in $250 \mathrm{cc}$ deionized water containing tetraethyl orthosilicate, in the next step, ultrasonic (Hielscher model, Sonication of liquids $0.5-4.0 \mathrm{~L} / \mathrm{min}$ ) was used to better separate the nanoparticles. Thereafter, 
Table 1 Properties of diazinon and alamar blue

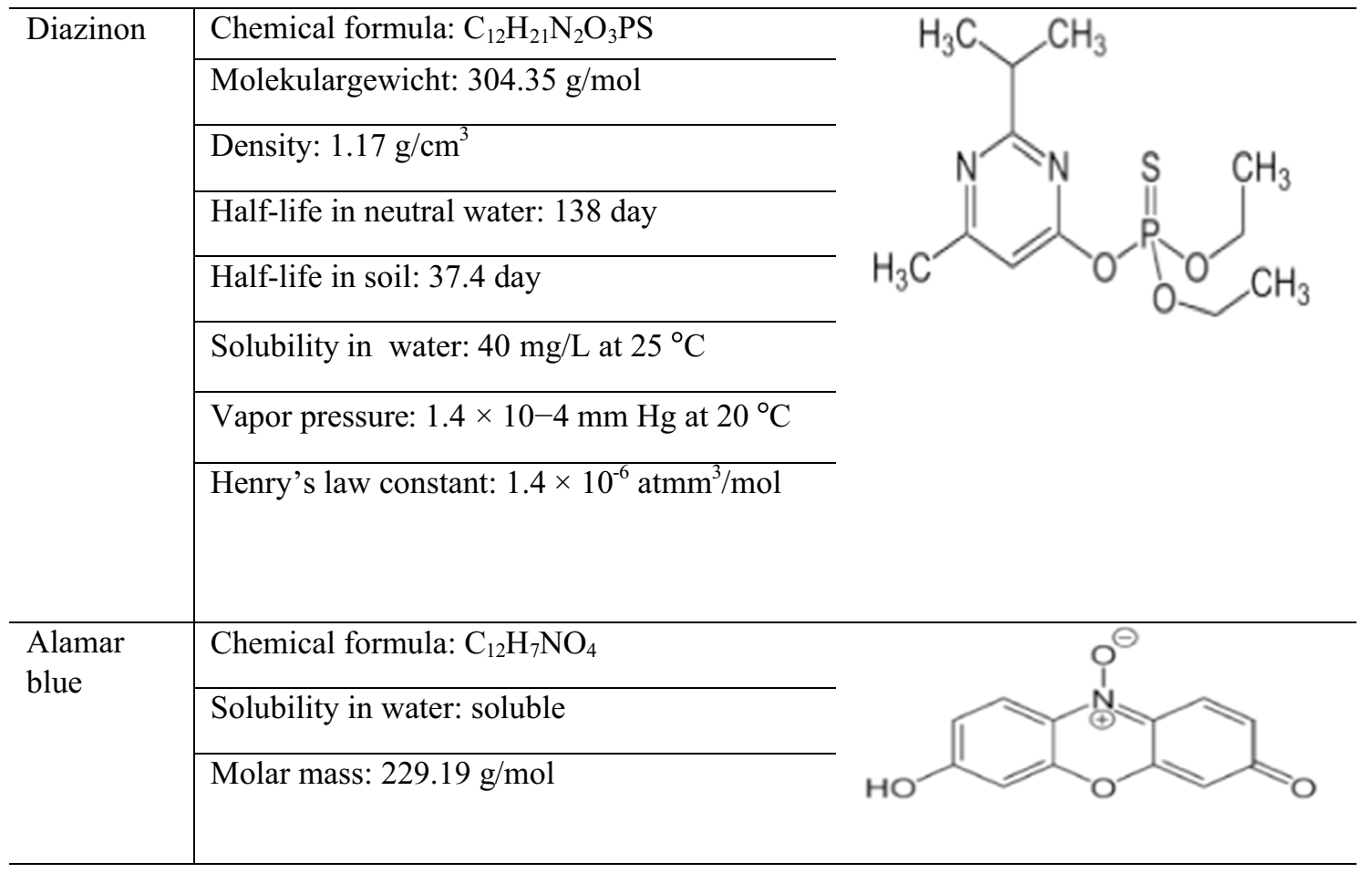

for transparency of nanoparticles and crystal formation, $30 \mathrm{~mL}$ of acetic acid was added to the reactor containing nanoparticles of iron/silica and mixed at $200 \mathrm{rpm}$. Next, the combination of acetic acid, ethanol and tetra-n-butyl lorthotitanate was prepared. The mixture obtained was added to the heater reactor and mixed at $500 \mathrm{rpm}$. After three stages of washing with deionized water and ethanol, $\mathrm{Fe}_{3} \mathrm{O}_{4} / \mathrm{SiO}_{2} / \mathrm{TiO}_{2}$ was formed (Shunxing et al. 2016; Toolabi et al. 2017; Wang et al. 2017). The surface and shape characteristics of the nano composite and quantitative analysis of the elements were characterized using a scanning electron microscope and energy dispersive $\mathrm{X}$-ray, respectively.

\section{Modeling and statistical analysis}

In this work, to model and design the experiments, response surface methodology (RSM) was used. This model is a collection of statistical and mathematical techniques that are useful for analyzing the effects of several independent variables on a response. RSM is an effective statistical technique for optimizing the number of experiments. Also, it specifies the interconnected amount of variables and the most optimal variable is presented in order of preference. RSM contains various models such as the Behnken design, central composite design (CCD), factorials method, box-d-optimal design etc. (Martino et al. 2015; Sarrai et al. 2016; Dehghani et al. 2017; Nama et al. 2018). In the present study, according to the CCD model, the number of experiments was designed for variables such as diazinon concentration (1-40 mg/L), contact time (10-120 $\mathrm{min}), \mathrm{pH}(3-12)$, and dose of nanoparticles (100-1000 mg/L), Table 2. Expert Design Ver 7 was used for the data analysis.

Table 2 The levels of variables central composite statistical experiment design

\begin{tabular}{llcrrr}
\hline Factor & Variables & Low actual & High actual & Mean & Std. Dev. \\
\hline A & pH & 2.012 & 7.500 & 9.75 & 5.25 \\
B & Contact time (min) & 24.597 & 65.000 & 92.50 & 37.50 \\
C & Concentration of diazinon(mg/L) & 8.721 & 20.500 & 30.25 & 10.75 \\
D & Dose of NPs (mg/L) & 201.246 & 550.000 & 775.00 & 325.00 \\
\hline
\end{tabular}




\section{Analytical procedures}

Experiments were conducted inside a glass reactor $(11 \times 11 \times 25 \mathrm{~cm})$ with a reflective wall. This reactor was equipped with a UV lamp $(\lambda=254 \mathrm{~nm}, \mathrm{P}=125 \mathrm{~W}$, $\mathrm{L}=10 \mathrm{~cm}$ ) surrounded by a quartz tube, cooling system, an air blower pump with a flow rate of $3 \mathrm{~L}$ per minute to remove gases from the reactor and also to prevent possible precipitation of nanoparticles to the bottom of the reactor, $\mathrm{pH}$ meter and multipara meter device. Also a radiometer device (model Hanger ECL-X) was used to measure the intensity of UV radiation. During the experiment process, sampling was done based on the CCD. In order to increase the production of radical hydroxyl ion in a solution, $\mathrm{H}_{2} \mathrm{O}_{2}$ compound was used at a concentration of $50 \mathrm{mg} / \mathrm{L}$ (Shemer and Linden 2006). All samples filtered by using a syringe equipped with a 0.2 micron filter. The concentration of diazinon was measured using High Performance Liquid Chromatography (HPLC), the following specifications were used; wavelength was $260 \mathrm{~nm}, \mathrm{C} 18$ column, length and diameter of the column were $4.6 \times 250 \mathrm{~mm}$ and the volume of injection sample $=20 \mu \mathrm{L}$. The removal efficiency of diazinon was obtained using the following Eq. 1.

$$
\operatorname{Removal}(\%)=\left(1-\mathrm{C}_{\mathrm{t}} / \mathrm{C}_{\mathrm{o}}\right) \times 100
$$

where $\mathrm{C}_{\mathrm{o}}$ is the initial concentrations of diazinon $(\mathrm{mg} / \mathrm{L})$ and $\mathrm{C}_{\mathrm{t}}$ is the residual of diazinon $(\mathrm{mg} / \mathrm{L})$ after the specified time.

By-products resulting from the degradation of diazinon were detected using gas chromatography-mass (GCMS) model Agilent Technologies 19091S-433 with a HP5MS column (length $25 \mathrm{~m}$, thickness $0.25 \mathrm{~mm}$, diameter $0.25 \mathrm{~mm}$ ) (Ehrampoush et al. 2017; Toolabi et al. 2017).

\section{Chemical oxygen demand (COD)}

Based on the standard methods in the purification of water sources, the rate of mineralization of diazinon was determined by measuring the COD. Accordingly, COD removal was determined using Eq. 2.

$$
\text { \%COD Removal }=\left(\frac{\mathrm{COD}_{\text {in }}-\mathrm{COD}_{\mathrm{r}}}{\mathrm{COD}_{\mathrm{in}}}\right)
$$

where $\mathrm{COD}_{\text {in }}$ is initial $\mathrm{COD}(\mathrm{mg} / \mathrm{L})$ and $\mathrm{COD}_{\mathrm{r}}$ is the COD $(\mathrm{mg} / \mathrm{L})$ residual concentration according to CCD parameters.

\section{Toxicity assessment based on ABR methods}

The rate of alamar blue dye reduction was determined by the activity of enzyme dehydrogenase; first broth nutrient culture medium was enriched with $\mathrm{KH}_{2} \mathrm{PO}_{4}(3.28 \mathrm{~g} / \mathrm{L})$, $\mathrm{K}_{2} \mathrm{HPO}_{4}(5.28 \mathrm{~g} / \mathrm{L})$, sodium acetate $(0.4 \mathrm{~g} / \mathrm{L})$ and glucose $(0.4 \mathrm{~g} / \mathrm{L})$. Next, $2 \mathrm{~mL}$ of $E$. coli suspension and $2 \mathrm{~mL}$ of alamar blue solution with concentration of $200 \mathrm{mg} / \mathrm{L}$ were added to the broth nutrient medium. Then, $1 \mathrm{~mL}$ of the diazinon was added with specific concentrations. Next, it was incubated at $30{ }^{\circ} \mathrm{C}$ under darkness condition. Following $60 \mathrm{~min}$ of contact time, $2 \mathrm{~mL}$ of $\mathrm{HCl}$-phthalate $0.05 \mathrm{M}$ buffer and $20 \mathrm{~mL}$ of $\mathrm{n}$-amyl alcohol solution were added to each test tube. Afterwards these materials were stirred slowly, The rate of alamar blue reduction was determined through the extent of absorption at the wavelength of $620 \mathrm{~nm}$ using $\mathrm{UV} / \mathrm{ViS}$ spectrophotometer device (Braic 2100) (Toolabi et al. 2017; Zare et al. 2016). The percentage of alamar blue reduction was obtained using Eq. 3.

$$
\begin{aligned}
& \text { Reduce activity of dehydrogenase } \\
& \text { enzyme in alamar blue conversion (\%) } \\
& =(\mathrm{A}-\mathrm{B}) / \mathrm{A} \times 100
\end{aligned}
$$

where $A$ is the rate of activity of dehydrogenase enzyme in the control sample and B is the rate of activity of dehydrogenase enzyme in the main sample.

\section{Toxicity assessment based on CFU methods}

To investigate the validity of ABR test and effluent bioassay, CFU test was conducted. Accordingly, first, a suspension of E. coli LMG bacteria was prepared. Suspension turbidity was detected using spectrophotometer device. Based on 0.5 McFarland, optical density (OD) 0.6 was generated. By measuring the turbidity in the suspension, the density of the bacterial cells was obtained in the range of $2-3 \times 10^{8}$ cells $/ \mathrm{mL}$. To determine the mortality rate of $E$. coli bacteria, $100 \mu \mathrm{L}$ of bacterial suspension was injected on a plate containing the Mueller-Hinton medium and diazinon (Nasiry et al. 2007; Gregoraszczuk et al. 2015; Balouiri et al. 2016; Tyc et al. 2016; Toolabi et al. 2017). After $24 \mathrm{~h}$ of incubation, the growth inhibition percentage was determined by Eq. 4 .

$$
\text { Growth inhibition percentage }=\mathrm{A}-\mathrm{B} / \mathrm{A} \times 100
$$

where $\mathrm{A}$ is the number of colonies of the control sample and $B$ is the number of colonies of the inoculated sample. Finally, for both tests (ABR and CFU), the results were reported as follows: The amount of toxin required for decreasing the growth less than $1 \%$ of the bacteria initial population was reported as no observed effect concentration (NOEC), the amount of toxin required for decreasing 50 and $100 \%$ of the bacterial growth was reported as effective concentration $\left(\mathrm{EC}_{50}\right)$ and effective concentration $\left(\mathrm{EC}_{100}\right)$, respectively.

\section{Sampling from natural source}

After determining the optimal parameters for removal of diazinon by advanced oxidation process, sampling of water from the Seymareh River was carried out for 6 
consecutive months. Sampling was carried out once a week and the volume of each sample $2 \mathrm{~L}$ was selected. After the samples were transferred to the laboratory, their physical and chemical characteristics were determined. Samples were introduced into the photocatalyst reactor. And removal efficiency of diazinon were obtained under optimum conditions. Then, Alamar Blue reduction and colony count unite tests were used to determine the toxicity of the effluent.

\section{Results}

\section{Scanning electron microscopy}

Information on surface morphology and particle size distribution of $\mathrm{Fe}_{3} \mathrm{O}_{4}$ and $\mathrm{Fe}_{3} \mathrm{O}_{4} / \mathrm{SiO}_{2} / \mathrm{TiO}_{2}$ were characterized using Scanning electron microscopy, Fig. 1. Accordingly, the high transparency of nanoparticles production was achieved with energy of $15 \mathrm{kV}$ and their accumulation properties were not observed. Also, according to the analysis of the size of the nanoparticles, the typical size of nanoparticles was determined to be $200 \mathrm{~nm}$.

\section{Energy dispersive X-ray spectroscopy}

According to Fig. 2, elemental composition analysis using EDX was presented at 0.2 to $8 \mathrm{keV}$. In $\mathrm{Fe}_{3} \mathrm{O}_{4} / \mathrm{SiO}_{2}$ composite, $\mathrm{O}, \mathrm{Fe}, \mathrm{Si}$, and $\mathrm{S}$ elements were diagnosed Fig. $2 \mathrm{a}$. The weakest and strongest signals were related to $S$ and Fe elements, respectively. It was also shown in Fig. $2 \mathrm{~b}$ that $\mathrm{Fe}_{3} \mathrm{O}_{4} / \mathrm{SiO}_{2} / \mathrm{TiO}_{2}$ nanoparticles contain $\mathrm{O}, \mathrm{C}, \mathrm{Fe}, \mathrm{Si}$, $\mathrm{Ti}, \mathrm{S}$, and $\mathrm{Cr}$ elements. The weakest and strongest signals were related to $\mathrm{Cr}$ and $\mathrm{O}$, respectively.

\section{Statistical analysis and modeling}

According to the central composite design, the number of 30 runs was designed and the efficiency removal of diazinon belonging to each run was determined, Table 3 . The optimum run was related to run 27; in this case, the removal efficiency of diazinon was reported to be $96.06 \%$. Also, the predicted value of each run was determined. Accordingly, a direct relationship between real values and predicted values was reported Fig. $3\left(R^{2}=0.943\right)$. Further details are shown in Table 3.

In this study, the regression results of quadratic, linear, 2FI, and cubic models for the removal efficiency of diazinon is shown in Table 4. Accordingly, for $\mathrm{R}^{2}=0.9865$, the quadratic model was more credible than other models. The final equation to describe the actual factors according to the quadratic model is shown in Eq. 5.

$$
\begin{aligned}
& \text { Removal efficiency of diazinon\% } \\
& \begin{aligned}
= & 89.26-3.528 \times \mathrm{A}-0.3342 \times \mathrm{B}-3.574 \\
& \times \mathrm{C}-3.023 \times \mathrm{D}-0.2713 \times \mathrm{AB}-0.1875 \times \mathrm{AC} \\
& -0.3050 \times \mathrm{AD}-0.3262 \times \mathrm{BC}-0.3988 \\
& \times \mathrm{BD}-0.3075 \times \mathrm{CD}-4.496 \times \mathrm{A}^{2} \\
& -2.586 \times \mathrm{B}^{2}-0.3646 \times \mathrm{C}^{2}-1.360 \times \mathrm{D}^{2}
\end{aligned}
\end{aligned}
$$

Based on Eq. 5, the maximum removal percentage of diazinon 96.06 was obtained. Impact coefficient for variables such as $\mathrm{pH}$, contact time, diazinon concentration, and dose of NPs was obtained 3.528, 0.3342, 3.574 and 3.023, respectively. As shown in Eq. 5, the main parameter
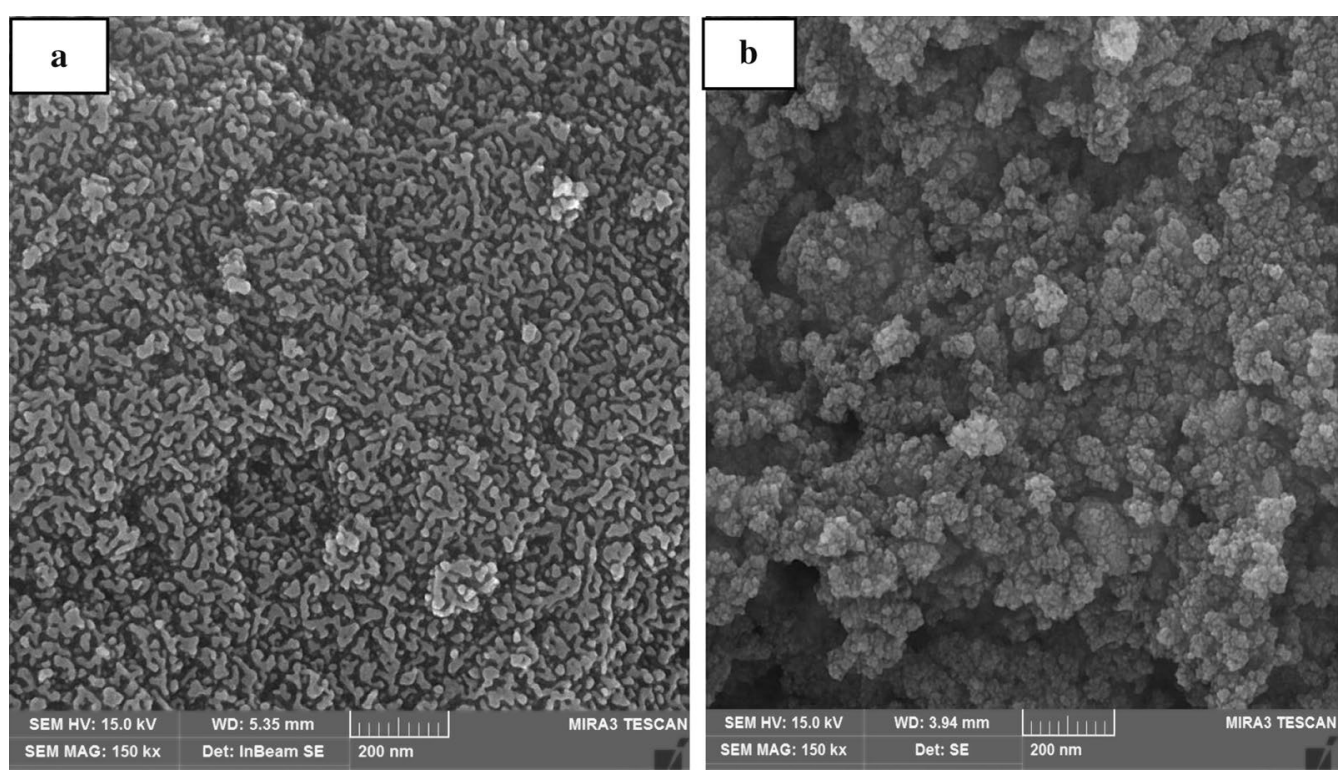

Fig. 1 The results of $\mathrm{SEM}$ images of $\mathbf{a} \mathrm{Fe}_{3} \mathrm{O}_{4}$ nanoparticles and $\mathbf{b} \mathrm{Fe}_{3} \mathrm{O}_{4} / \mathrm{SiO}_{2} / \mathrm{TiO}_{2}$ nanoparticles 


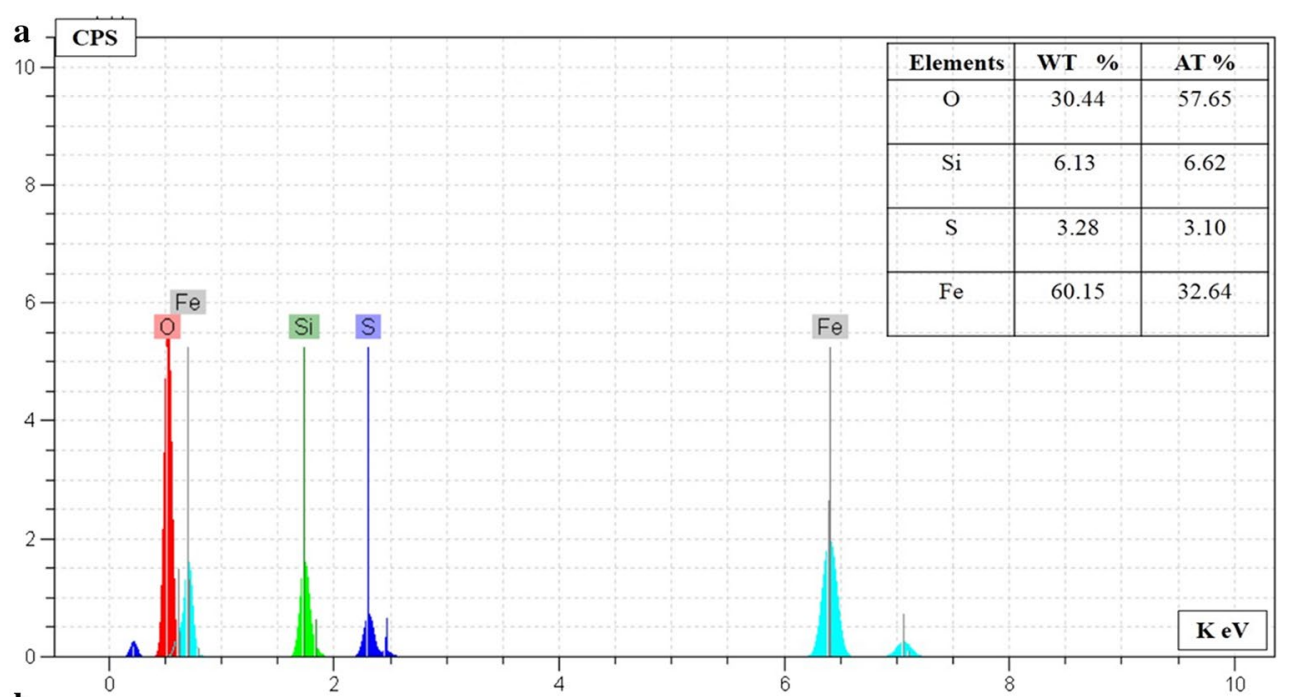

b

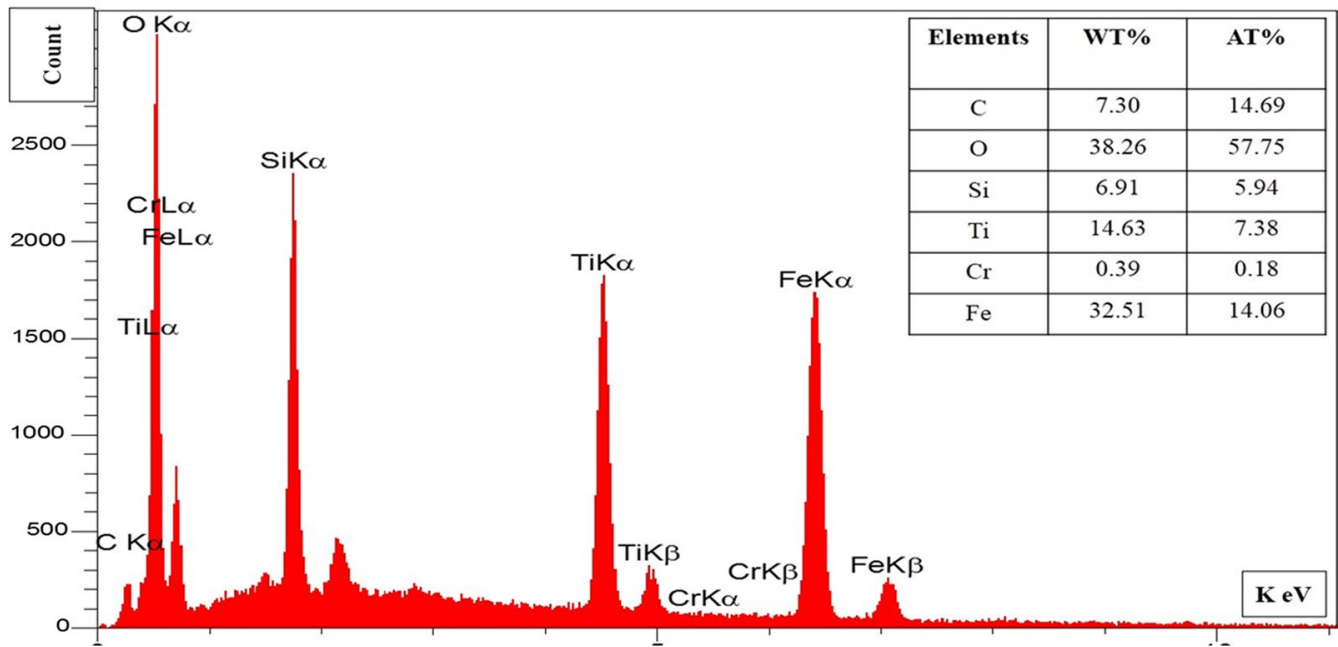

Fig. 2 EDX spectrum of $\mathbf{a} \mathrm{Fe}_{3} \mathrm{O}_{4} / \mathrm{SiO}_{2}$ and $\mathbf{b} \mathrm{Fe}_{3} \mathrm{O}_{4} / \mathrm{SiO}_{2} / \mathrm{TiO}_{2}$ nanoparticles

is related to the $\mathrm{pH}$ variable. Also, the minimum and maximum interaction amount variables in relation to the coefficient of $\mathrm{AC}$ and $\mathrm{BD}$ Coded Factors were obtained as 0.1875 and 0.3988 , respectively. In this study, the F-value, $\mathrm{P}$ value and degree of freedom (DF) parameters were conducted for the analysis of variance. According to the results shown in Table 5, the F-value, P-value and DF were obtained as $78.32,<0.0001$, and 14 , respectively.

\section{Effect of variables on the removal efficiency}

The results indicated that this process has been highly efficient in the removal of diazinon and COD. As shown in Figs. 3, 4, D response and contour plot models were studied for the removal of diazinon. The effect of the initial concentration of diazinon in the reactor was investigated from 1 to $40 \mathrm{mg} / \mathrm{L}$. As shown in Fig. 4, by increasing the initial concentration of diazinon, the removal efficiency decreased. Accordingly, at $\mathrm{pH}=6.75$ and contact time $=65 \mathrm{~min}$, by increasing the initial concentration from 10.75 to $30.25 \mathrm{mg} / \mathrm{L}$, removal efficiency of diazinon decreased from 92 to $85 \%$. The optimal $\mathrm{pH}$ for diazinon removal was obtained near 7 . When $\mathrm{pH}$ increased from 6.75 to 9.5 , the removal efficiency of diazinon decreased from 90.5 to $82 \%$. Also, in this study, optimal contact time and optimal dose of nanoparticles were obtained in $65 \mathrm{~min}$ and $775 \mathrm{mg} / \mathrm{L}$, respectively, Fig. 4.

\section{Identification of products by GC-MS}

In this study, the analysis of by-products was performed based on the following conditions; $\mathrm{pH}=6.75$, contact time $=40-80 \mathrm{~min}$, dose of NPs $=775 \mathrm{mg} / \mathrm{L}$ and diazinon Concentration $=10.75 \mathrm{mg} / \mathrm{L}$. Speciation and molecular 
Table 3 Results of the experimental runs based on the central composite design

\begin{tabular}{|c|c|c|c|c|c|c|}
\hline Run & $\mathrm{A}: \mathrm{PH}$ & $\begin{array}{l}\text { B:Contact time } \\
\text { (min) }\end{array}$ & $\begin{array}{l}\text { C:Concentration of } \\
\text { diazinon }(\mathrm{mg} / \mathrm{L})\end{array}$ & $\begin{array}{l}\text { D:Dosage of } \\
\text { nanoparticles }(\mathrm{mg} / \mathrm{L})\end{array}$ & Removal efficiency (\%) & Predicted value \\
\hline 1 & 7.500 & 65.00 & 20.50 & 550.0 & 88.90 & 89.26 \\
\hline 2 & 7.500 & 65.00 & 20.50 & 550.0 & 88.68 & 89.26 \\
\hline 3 & 7.500 & 65.00 & 20.50 & 550.0 & 87.99 & 89.26 \\
\hline 4 & 7.500 & 65.00 & 20.50 & 550.0 & 88.39 & 89.26 \\
\hline 5 & 7.500 & 65.00 & 20.50 & 550.0 & 90.91 & 89.26 \\
\hline 6 & 7.500 & 65.00 & 20.50 & 550.0 & 90.70 & 89.26 \\
\hline 7 & 5.250 & 37.50 & 10.75 & 325.0 & 83.60 & 83.67 \\
\hline 8 & 9.750 & 37.50 & 10.75 & 325.0 & 77.24 & 76.92 \\
\hline 9 & 5.250 & 92.50 & 10.75 & 325.0 & 84.10 & 85.02 \\
\hline 10 & 9.750 & 92.50 & 10.75 & 325.0 & 77.33 & 77.19 \\
\hline 11 & 5.250 & 37.50 & 30.25 & 325.0 & 76.30 & 76.86 \\
\hline 12 & 9.750 & 37.50 & 30.25 & 325.0 & 70.10 & 69.36 \\
\hline 13 & 5.250 & 92.50 & 30.25 & 325.0 & 81.17 & 79.52 \\
\hline 14 & 9.750 & 92.50 & 30.25 & 325.0 & 71.23 & 70.93 \\
\hline 15 & 5.250 & 37.50 & 10.75 & 775.0 & 90.00 & 90.52 \\
\hline 16 & 9.750 & 37.50 & 10.75 & 775.0 & 84.00 & 84.99 \\
\hline 17 & 5.250 & 92.50 & 10.75 & 775.0 & 90.20 & 90.28 \\
\hline 18 & 9.750 & 92.50 & 10.75 & 775.0 & 84.00 & 83.66 \\
\hline 19 & 5.250 & 37.50 & 30.25 & 775.0 & 83.00 & 82.47 \\
\hline 20 & 9.750 & 37.50 & 30.25 & 775.0 & 76.90 & 76.20 \\
\hline 21 & 5.250 & 92.50 & 30.25 & 775.0 & 83.00 & 83.54 \\
\hline 22 & 9.750 & 92.50 & 30.25 & 775.0 & 76.91 & 76.18 \\
\hline 23 & 3.000 & 65.00 & 20.50 & 550.0 & 78.81 & 78.33 \\
\hline 24 & 12.00 & 65.00 & 20.50 & 550.0 & 63.30 & 64.22 \\
\hline 25 & 7.500 & 10.00 & 20.50 & 550.0 & 78.39 & 78.25 \\
\hline 26 & 7.500 & 65.00 & 20.50 & 550.0 & 79.00 & 79.59 \\
\hline 27 & 7.500 & 65.00 & 1.000 & 550.0 & 96.06 & 94.95 \\
\hline 28 & 7.500 & 65.00 & 40.00 & 550.0 & 79.10 & 80.66 \\
\hline 29 & 7.500 & 65.00 & 20.50 & 100.0 & 77.20 & 77.78 \\
\hline 30 & 7.500 & 65.00 & 20.50 & 1000 & 90.00 & 89.87 \\
\hline
\end{tabular}

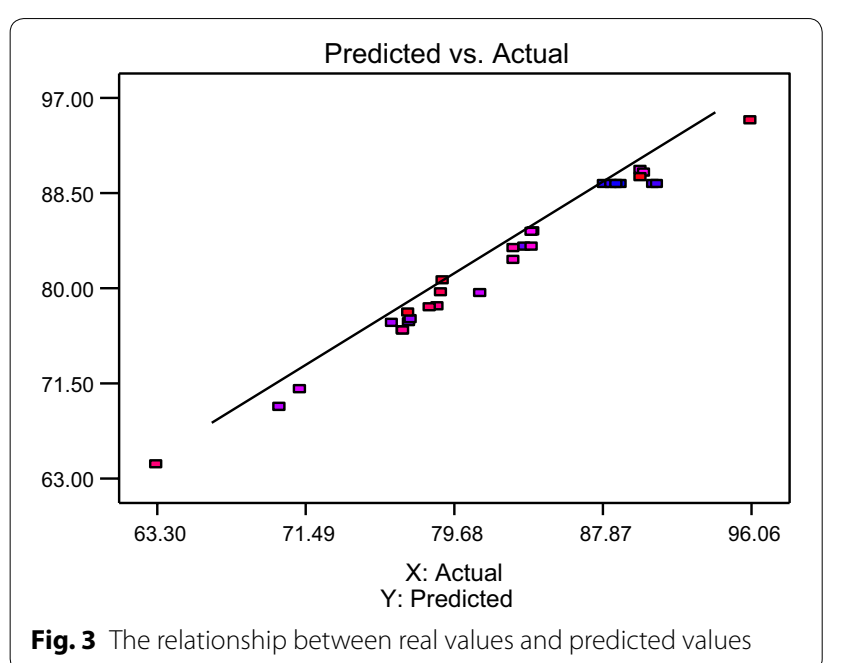

structures of the oxidation by-products were analyzed by GC-MS, Fig. 5. According to the results shown in Table 6, four by-products, including; diazoxon, 7-methyl3-octyne, 2-isopropyl-6-methyl-4-pyrimidinol (IMP) and diethyl phosphonate were identified during degradation of diazinon. Their retention time (RT) varied from 2.15 to $15.75 \mathrm{~min}$. As such, the minimum and maximum RT were related to diazoxon and diethyl phosphonate compounds, respectively. The characteristics of other compounds are shown in Table 6.

\section{Effluent toxicity assessment}

In this study, to determine the mortality rate of E. coli LMG bacterial, NOEC, effective concentration (EC) parameter was used. Accordingly, the growth inhibitory level Before and after from performing the advanced 
Table 4 The results of Statistics Model

\begin{tabular}{lllllc}
\hline Source & Std. Dev & $\mathbf{R}^{\mathbf{2}}$ & Adjusted $\mathbf{R}^{\mathbf{2}}$ & Predicted $\mathbf{R}^{\mathbf{2}}$ & PRESS \\
\hline Linear & 5.313 & 0.5397 & 0.4660 & 0.3788 & 952.3 \\
2FI & 6.056 & 0.5455 & 0.3063 & 0.2559 & 1141 \\
Quadratic & 1.174 & 0.9865 & 0.9739 & 0.9438 & 86.20 \\
Cubic & 1.135 & 0.9941 & 0.9756 & 0.8630 & 210.0 \\
\hline
\end{tabular}

Table 5 ANOVA of Response Surface Quadratic Model

\begin{tabular}{|c|c|c|c|c|c|}
\hline Source & Sum of squares & Df & $\begin{array}{l}\text { Mean } \\
\text { square }\end{array}$ & $\begin{array}{l}F \\
\text { value }\end{array}$ & $\begin{array}{l}\text { P value } \\
\text { Prob }>F\end{array}$ \\
\hline Model & 1512 & 14 & 108 & 78.32 & $\begin{array}{l}<0.0001 \\
\text { significant }\end{array}$ \\
\hline A & 298.8 & 1 & 298.8 & 216.6 & $<0.0001$ \\
\hline B & 2.680 & 1 & 2.680 & 1.943 & 0.1836 \\
\hline C & 306.6 & 1 & 306.2 & 222.3 & $<0.0001$ \\
\hline D & 219.3 & 1 & 219.3 & 159.0 & $<0.0001$ \\
\hline$A B$ & 1.177 & 1 & 1.177 & 0.853 & 0.3702 \\
\hline$A C$ & 0.562 & 1 & 0.562 & 0.407 & 0.5327 \\
\hline$A D$ & 1.488 & 1 & 1.480 & 1.079 & 0.3154 \\
\hline$B C$ & 1.703 & 1 & 1.703 & 1.235 & 0.2840 \\
\hline $\mathrm{BD}$ & 2.544 & 1 & 2.540 & 1.844 & 0.1945 \\
\hline$C D$ & 1.513 & 1 & 1.513 & 1.097 & 0.3154 \\
\hline$A^{2}$ & 554.4 & 1 & 554.4 & 401.9 & $<0.0001$ \\
\hline$B^{2}$ & 183.4 & 1 & 183.4 & 133.0 & $<0.0001$ \\
\hline$C^{2}$ & 3.645 & 1 & 3.646 & 2.643 & 0.1248 \\
\hline$D^{2}$ & 50.70 & 1 & 50.70 & 36.76 & $<0.0001$ \\
\hline Residual & 20.69 & 15 & 1.379 & - & - \\
\hline Lack of fit & 13.06 & 10 & 1.306 & 0.855 & $\begin{array}{l}0.617 \text { not } \\
\text { significant }\end{array}$ \\
\hline Pure error & 7.63 & 5 & 1.526 & - & - \\
\hline Cor total & 1533 & 29 & - & - & - \\
\hline
\end{tabular}

Df Degree of freedom

oxidation process (AOP) was obtained. $\mathrm{EC}_{50}$ related to $\mathrm{ABR}$ and CFU tests before from performing AOP was obtained as 2.255 and $2.250 \mathrm{mg} / \mathrm{L}$, respectively, Also, NOEC related to ABR and CFU tests was obtained as 0.890 and $0.850 \mathrm{mg} / \mathrm{L}$, respectively, Table 7 . Based on the results shown in Table 8, the effluent toxicity assessment from the reactor in different runs for $\mathrm{EC}_{50}$ and NOEC parameters related to ABR test after from performing AOP were obtained as 2.275 and $0.839 \mathrm{mg} / \mathrm{L}$, respectively.

\section{Analysis of the river water samples}

The characteristics of raw water of Seymareh Rive are shown in Table 9, Based on the results of analysis of the River water samples, it was found that the removal efficiency of diazinon by advanced oxidation process is $95 \%$, and it was found that the COD was decreased from 55 to $1.65 \mathrm{mg} / \mathrm{L}$. By analyzing the effluent toxicity Using Alamar blue and colony forming unit tests, it was observed that the number of bacteria are not decreased.

\section{Discussion}

According to the results obtained in Fig. 1, it was found that the syntheses of $\mathrm{Fe}_{3} \mathrm{O}_{4} / \mathrm{SiO}_{2} / \mathrm{TiO}_{2}$ nanoparticles were successful. By using SEM techniques, the size of the nanoparticles was confirmed at a range of $200 \mathrm{~nm}$. Also, by comparing the elements and peaks produced by EDX analysis, It was found that sol-gel and co-precipitation methods were acceptable for the synthesis of nanoparticles in this study.

According to the analysis of variance Table 5, values of Prob $>\mathrm{F}$ less than 0.0500 show that the model quality is significant. Accordingly, the $A, C, D, A_{2}, B_{2}$, and $D_{2}$ parameters are significant. The $F$ value of 78.32 and the Prob $>F$ value of $<0.0001$ suggest that the model was statistically approved for removal of diazinon. Also, based on the results obtained from the quadratic model in Table 4 , the $R^{2}$ value and Adj $R^{2}$ value were obtained as 0.986 and 0.973 , respectively. These results showed that the predicted values obtained from the quadratic model is a fit of the experimental results (Martino et al. 2015; Sarrai et al. 2016; Dehghani et al. 2017).

In order to increase the photo catalytic properties in the process, hydrogen peroxide was added to the reactor. Hydrogen peroxide led to more formation of hydroxyl radicals and resulted in the oxidation of the pesticide compounds (Fadaei et al. 2012; Asaithambi et al. 2017). According to the results obtained in Fig. 4, by increasing the contact time from 37 to $65 \mathrm{~min}$, removal efficiency of diazinon was increased from 85.5 to $91 \%$. This is due to the production of more $\mathrm{OH}$ radicals in longer time and also more exposure of active radicals by diazinon; the possibility of the decomposition of a larger percentage of diazinon is provided. Based on the results from the one factor response model, three-dimensional response and contour model, by increasing the concentration of NPs, the removal efficiency of diazinon was increased.

(See figure on next page.)

Fig. 4 Contour model and 3-D response for removal of diazinon with interactions among factors, $\mathbf{a}$ contact time $=65 \mathrm{~min}$ and dose of $\mathrm{NPs}=775 \mathrm{mg} / \mathrm{L}$, b dose of NPs $=775 \mathrm{mg} / \mathrm{L}$, concentrations of diazinon $=10.75 \mathrm{mg} / \mathrm{L}$, $\mathbf{c}$ concentration of diazinon $=10.75 \mathrm{mg} / \mathrm{L}$ and contact time $=65 \mathrm{~min}, \mathbf{d ~ p H}=6.5$ and contact time $=65 \mathrm{~min}, \mathbf{e ~} \mathrm{pH}=6.5$ and dose of NPs $=775 \mathrm{mg} / \mathrm{L}, \mathbf{f}$ concentration of diazinon $=10.75 \mathrm{mg} / \mathrm{L}$ and $\mathrm{pH}=6.5$ 

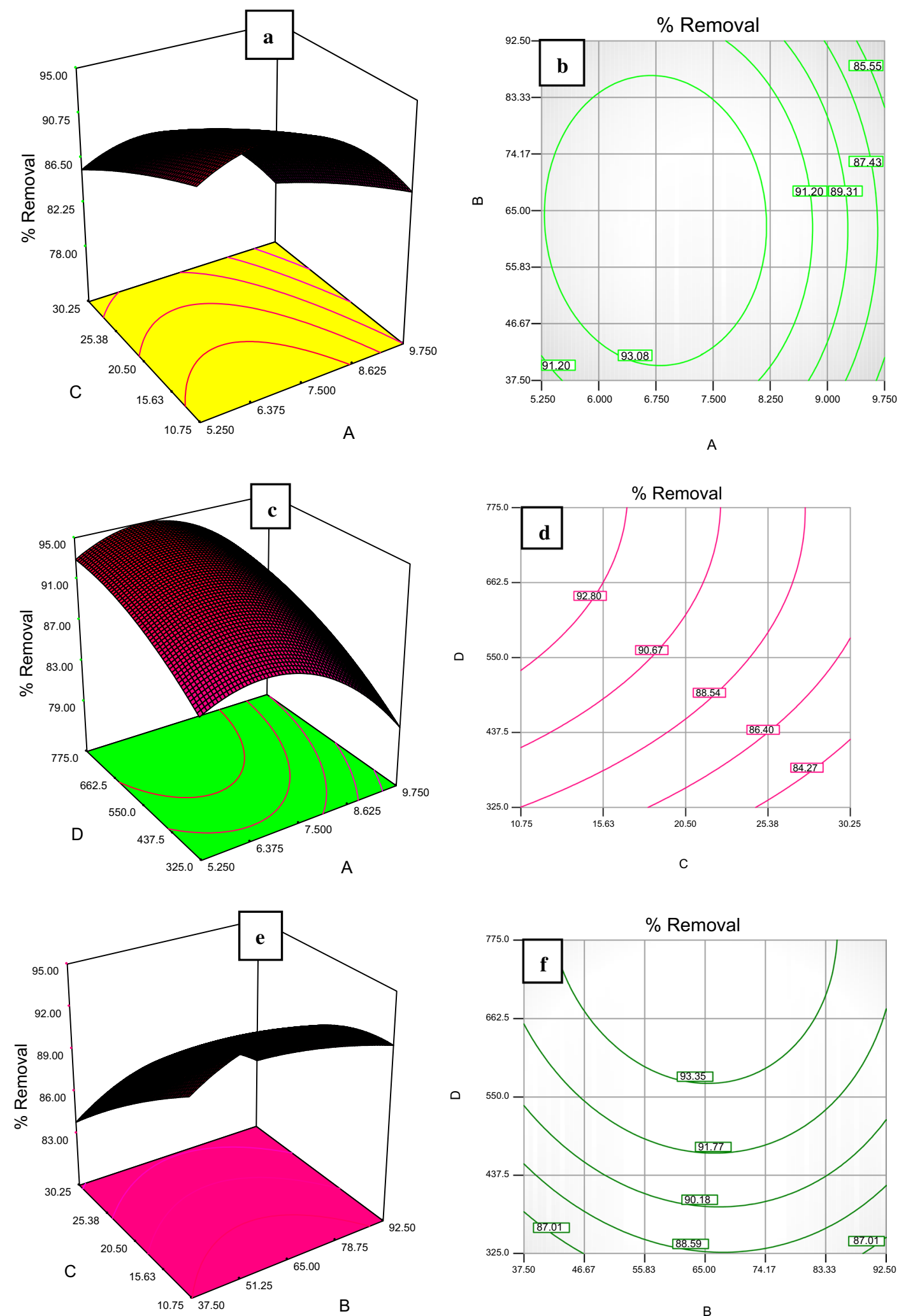


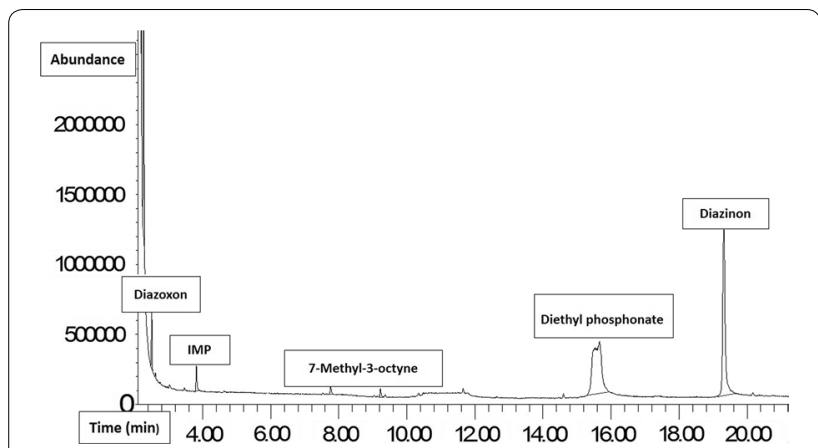

Fig. 5 Gas chromatography-mass spectrometry of diazinon

Therefore, at a dosage of $320 \mathrm{mg} / \mathrm{L}$ of NPs, the removal percentage of diazinon was obtained at 85 . Once the dosage of NPs was increased to $775 \mathrm{mg} / \mathrm{L}$, the removal percentage of diazinon reached 92.5 . This is because, when the concentration of nanoparticles under the influence of UV radiation is increased in the reactor test, $\mathrm{h}^{+}$and $\mathrm{e}^{-}$ions are produced. Afterwards, these ions react with water and peroxide radicals and also hydroxide ions are produced (Shunxing et al. 2016; Toolabi et al. 2017). Peroxide radicals are mixed with $\mathrm{H}^{+}$ions and hydroxyl radicals $\left(\mathrm{OH}^{*}\right)$ are formed. Due to the high oxidation power of $\mathrm{OH}$ radicals, the degradation of the diazinon occurred. In this study, it was found that due to the reflective wall of the reactor, the amount of radiation produced is 1.45 times higher than that of conventional reactors under similar conditions. This causes more electrons to be stimulated from the catalyst surface, and the production of active radicals in the solution increased.

Based on the results of this study, $\mathrm{pH}$ was the most effective parameter in removing diazinon. The maximum removal efficiency was obtained when $\mathrm{pH}$ was equal to 6.75 , this was because more hydrolysis of diazinon occurs in acidic solutions. Also, the production of active hydroxyl radicals is higher in acidic solutions. Therefore, this parameter should be given more attention in future studies (Li et al. 2015; Ehrampoush et al. 2017; Toolabi et al. 2017). In the study of Kalantary et al., optimal parameters such as $\mathrm{pH}$ of the nanoparticle and the contact time degradation of diazinon were obtained by using the $\mathrm{TiO}_{2} / \mathrm{UV}$ process at 6 , and $550 \mathrm{mg} / \mathrm{L}$, and $60 \mathrm{~min}$,
Table 7 The result of diazinon effect concentration in ABR and CFU tests by using $E$. coli

\begin{tabular}{|c|c|c|c|c|}
\hline Parameters & Type of test & $\begin{array}{l}\text { Bottom } \\
\text { limit }\end{array}$ & Upper limit & Typical value \\
\hline $\mathrm{EC}_{5}(\mathrm{mg} / \mathrm{L})$ & $\begin{array}{l}\text { ABR } \\
\text { CFU }\end{array}$ & $\begin{array}{l}0.316 \\
0.313\end{array}$ & $\begin{array}{l}0.329 \\
0.323\end{array}$ & $\begin{array}{l}0.324 \\
0.319\end{array}$ \\
\hline $\mathrm{EC}_{10}(\mathrm{mg} / \mathrm{L})$ & $\begin{array}{l}\text { ABR } \\
\text { CFU }\end{array}$ & $\begin{array}{l}0.519 \\
0.515\end{array}$ & $\begin{array}{l}0.533 \\
0.529\end{array}$ & $\begin{array}{l}0.530 \\
0.525\end{array}$ \\
\hline $\mathrm{EC}_{15}(\mathrm{mg} / \mathrm{L})$ & $\begin{array}{l}\text { ABR } \\
\text { CFU }\end{array}$ & $\begin{array}{l}0.817 \\
0816\end{array}$ & $\begin{array}{l}0.829 \\
0.825\end{array}$ & $\begin{array}{l}0.823 \\
0.820\end{array}$ \\
\hline $\mathrm{EC}_{20}(\mathrm{mg} / \mathrm{L})$ & $\begin{array}{l}\text { ABR } \\
\text { CFU }\end{array}$ & $\begin{array}{l}0.959 \\
0.950\end{array}$ & $\begin{array}{l}1.000 \\
0.987\end{array}$ & $\begin{array}{l}0.968 \\
0.964\end{array}$ \\
\hline $\mathrm{EC}_{25}(\mathrm{mg} / \mathrm{L})$ & $\begin{array}{l}\text { ABR } \\
\text { CFU }\end{array}$ & $\begin{array}{l}1.287 \\
1.272\end{array}$ & $\begin{array}{l}1.297 \\
1.287\end{array}$ & $\begin{array}{l}1.293 \\
1.285\end{array}$ \\
\hline $\mathrm{EC}_{30}(\mathrm{mg} / \mathrm{L})$ & $\begin{array}{l}\text { ABR } \\
\text { CFU }\end{array}$ & $\begin{array}{l}1.502 \\
1.489\end{array}$ & $\begin{array}{l}1.513 \\
1.508\end{array}$ & $\begin{array}{l}1.510 \\
1.500\end{array}$ \\
\hline $\mathrm{EC}_{35}(\mathrm{mg} / \mathrm{L})$ & $\begin{array}{l}\text { ABR } \\
\text { CFU }\end{array}$ & $\begin{array}{l}1.612 \\
1.609\end{array}$ & $\begin{array}{l}1.630 \\
1.621\end{array}$ & $\begin{array}{l}1.619 \\
1.611\end{array}$ \\
\hline $\mathrm{EC}_{40}(\mathrm{mg} / \mathrm{L})$ & $\begin{array}{l}\text { ABR } \\
\text { CFU }\end{array}$ & $\begin{array}{l}1.826 \\
1.812\end{array}$ & $\begin{array}{l}1.831 \\
1.852\end{array}$ & $\begin{array}{l}1.826 \\
1.818\end{array}$ \\
\hline $\mathrm{EC}_{45}(\mathrm{mg} / \mathrm{L})$ & $\begin{array}{l}\text { ABR } \\
\text { CFU }\end{array}$ & $\begin{array}{l}2.030 \\
2.022\end{array}$ & $\begin{array}{l}2.041 \\
2.032\end{array}$ & $\begin{array}{l}2.034 \\
2.027\end{array}$ \\
\hline $\mathrm{EC}_{50}(\mathrm{mg} / \mathrm{L})$ & $\begin{array}{l}\text { ABR } \\
\text { CFU }\end{array}$ & $\begin{array}{l}2.230 \\
2.235\end{array}$ & $\begin{array}{l}2.265 \\
2.255\end{array}$ & $\begin{array}{l}2.255 \\
2.250\end{array}$ \\
\hline $\mathrm{EC}_{55}(\mathrm{mg} / \mathrm{L})$ & $\begin{array}{l}\text { ABR } \\
\text { CFU }\end{array}$ & $\begin{array}{l}2.360 \\
2.339\end{array}$ & $\begin{array}{l}2.372 \\
2.351\end{array}$ & $\begin{array}{l}2.363 \\
2.347\end{array}$ \\
\hline $\mathrm{EC}_{60}(\mathrm{mg} / \mathrm{L})$ & $\begin{array}{l}\text { ABR } \\
\text { CFU }\end{array}$ & $\begin{array}{l}2.584 \\
2.545\end{array}$ & $\begin{array}{l}2.591 \\
2.577\end{array}$ & $\begin{array}{l}2.587 \\
2.571\end{array}$ \\
\hline $\mathrm{EC}_{65}(\mathrm{mg} / \mathrm{L})$ & $\begin{array}{l}\text { ABR } \\
\text { CFU }\end{array}$ & $\begin{array}{l}2.719 \\
2.761\end{array}$ & $\begin{array}{l}2.732 \\
2.795\end{array}$ & $\begin{array}{l}2.724 \\
2.790\end{array}$ \\
\hline $\mathrm{EC}_{70}(\mathrm{mg} / \mathrm{L})$ & $\begin{array}{l}\text { ABR } \\
\text { CFU }\end{array}$ & $\begin{array}{l}2.932 \\
2.900\end{array}$ & $\begin{array}{l}2.961 \\
2.920\end{array}$ & $\begin{array}{l}2.951 \\
2.911\end{array}$ \\
\hline$E C_{75}(\mathrm{mg} / \mathrm{L})$ & $\begin{array}{l}\text { ABR } \\
\text { CFU }\end{array}$ & $\begin{array}{l}3.100 \\
3.127\end{array}$ & $\begin{array}{l}3.125 \\
3.149\end{array}$ & $\begin{array}{l}3.111 \\
3.145\end{array}$ \\
\hline $\mathrm{EC}_{80}(\mathrm{mg} / \mathrm{L})$ & $\begin{array}{l}\text { ABR } \\
\text { CFU }\end{array}$ & $\begin{array}{l}3.329 \\
3.351\end{array}$ & $\begin{array}{l}3.343 \\
3.371\end{array}$ & $\begin{array}{l}3.335 \\
3.360\end{array}$ \\
\hline $\mathrm{EC}_{85}(\mathrm{mg} / \mathrm{L})$ & $\begin{array}{l}\text { ABR } \\
\text { CFU }\end{array}$ & $\begin{array}{l}3.742 \\
3.668\end{array}$ & $\begin{array}{l}3.659 \\
3.702\end{array}$ & $\begin{array}{l}3.652 \\
3.689\end{array}$ \\
\hline $\mathrm{EC}_{90}(\mathrm{mg} / \mathrm{L})$ & $\begin{array}{l}\text { ABR } \\
\text { CFU }\end{array}$ & $\begin{array}{l}3.878 \\
3.890\end{array}$ & $\begin{array}{l}3.888 \\
3.823\end{array}$ & $\begin{array}{l}3.881 \\
3.812\end{array}$ \\
\hline $\mathrm{EC}_{95}(\mathrm{mg} / \mathrm{L})$ & $\begin{array}{l}\text { ABR } \\
\text { CFU }\end{array}$ & $\begin{array}{l}4.000 \\
3.975\end{array}$ & $\begin{array}{l}4.116 \\
4.120\end{array}$ & $\begin{array}{l}4.080 \\
4.020\end{array}$ \\
\hline NOEC (mg/L) & $\begin{array}{l}\text { ABR } \\
\text { CFU }\end{array}$ & $\begin{array}{l}0.884 \\
0.847\end{array}$ & $\begin{array}{l}0.893 \\
0.859\end{array}$ & $\begin{array}{l}0.890 \\
0.850\end{array}$ \\
\hline $\mathrm{EC}_{100}(\mathrm{mg} / \mathrm{L})$ & $\begin{array}{l}\text { ABR } \\
\text { CFU }\end{array}$ & $\begin{array}{l}4.010 \\
3.980\end{array}$ & $\begin{array}{l}4.300 \\
4.221\end{array}$ & $\begin{array}{l}4.128 \\
4.120\end{array}$ \\
\hline
\end{tabular}

Table 6 The characteristics of by-products identification due to diazinon decomposition

\begin{tabular}{llll}
\hline Compound name & Molecular formula & Retention time (min) & Molecular weight (g/mol) \\
\hline Diazoxon & $\mathrm{C}_{12} \mathrm{H}_{21} \mathrm{~N}_{2} \mathrm{O}_{4} \mathrm{P}$ & 2.15 & 288.284 \\
2-isopropyl-6-methyl-pyrimidin-4-ol (IMP) & $\mathrm{C}_{8} \mathrm{H}_{12} \mathrm{~N}_{2} \mathrm{O}$ & 3.25 & 152.197 \\
7-Methyl-3-octyne & $\mathrm{C}_{9} \mathrm{H}_{16}$ & 7.65 & 124.223 \\
Diethyl phosphonate & $\mathrm{C}_{4} \mathrm{H}_{10} \mathrm{O}_{3} \mathrm{P}^{+}$ & 15.75 & 137.095 \\
\hline
\end{tabular}


Table 8 The result of COD Removal, ORP and bioassay test to determination of effluent toxicity in different Runs

\begin{tabular}{|c|c|c|c|c|c|}
\hline \multirow[t]{2}{*}{ Run } & \multirow[t]{2}{*}{ COD removal \% } & \multirow[t]{2}{*}{$\mathrm{ORP}(\mathrm{mv})$} & \multirow[t]{2}{*}{ Residuals of diazinon (mg/L) } & \multicolumn{2}{|c|}{ Rate of EC, NOEC } \\
\hline & & & & ABR test & CFU test \\
\hline 1 & 94.50 & 333 & 2.275 & $\mathrm{EC}_{50}$ & $\mathrm{EC}_{49}$ \\
\hline 2 & 96.00 & 330 & 2.320 & $\mathrm{EC}_{55}$ & $\mathrm{EC}_{56}$ \\
\hline 3 & 94.40 & 325 & 2.462 & $\mathrm{EC}_{62}$ & $\mathrm{EC}_{59}$ \\
\hline 4 & 95.30 & 322 & 2.585 & $\mathrm{EC}_{65}$ & $\mathrm{EC}_{56}$ \\
\hline 5 & 96.00 & 339 & 1.863 & $\mathrm{EC}_{40}$ & $\mathrm{EC}_{37}$ \\
\hline 6 & 95.70 & 337 & 1.906 & $\mathrm{EC}_{42}$ & $\mathrm{EC}_{38}$ \\
\hline 7 & 93.90 & 338 & 1.763 & $\mathrm{EC}_{41}$ & $\mathrm{EC}_{35}$ \\
\hline 8 & 92.80 & 327 & 2.446 & $\mathrm{EC}_{58}$ & $\mathrm{EC}_{53}$ \\
\hline 9 & 94.00 & 341 & 1.709 & $\mathrm{EC}_{37}$ & $\mathrm{EC}_{33}$ \\
\hline 10 & 92.80 & 331 & 2.437 & $\mathrm{EC}_{55}$ & $\mathrm{EC}_{50}$ \\
\hline 11 & 92.10 & - & 7.169 & $\mathrm{EC}_{100}$ & $\mathrm{EC}_{100}$ \\
\hline 12 & 88.90 & - & 9.044 & $\mathrm{EC}_{100}$ & $\mathrm{EC}_{100}$ \\
\hline 13 & 93.50 & - & 5.683 & $\mathrm{EC}_{100}$ & $\mathrm{EC}_{100}$ \\
\hline 14 & 90.00 & - & 8.702 & $\mathrm{EC}_{100}$ & $\mathrm{EC}_{100}$ \\
\hline 15 & 96.90 & 349 & 1.075 & $\mathrm{EC}_{22}$ & $\mathrm{EC}_{19}$ \\
\hline 16 & 96.00 & 340 & 1.720 & $\mathrm{EC}_{39}$ & $\mathrm{EC}_{35}$ \\
\hline 17 & 93.80 & 350 & 1.075 & $\mathrm{EC}_{20}$ & $\mathrm{EC}_{18}$ \\
\hline 18 & 91.50 & 340 & 1.720 & $\mathrm{EC}_{40}$ & $\mathrm{EC}_{37}$ \\
\hline 19 & 93.50 & - & 5.142 & $\mathrm{EC}_{100}$ & $\mathrm{EC}_{100}$ \\
\hline 20 & 92.00 & - & 6.987 & $\mathrm{EC}_{100}$ & $\mathrm{EC}_{100}$ \\
\hline 21 & 93.80 & - & 5.142 & $\mathrm{EC}_{100}$ & $\mathrm{EC}_{100}$ \\
\hline 22 & 92.00 & - & 6.985 & $\mathrm{EC}_{100}$ & $\mathrm{EC}_{100}$ \\
\hline 23 & 93.20 & - & 4.434 & $\mathrm{EC}_{100}$ & $\mathrm{EC}_{100}$ \\
\hline 24 & 85.00 & - & 7.523 & $\mathrm{EC}_{100}$ & $\mathrm{EC}_{100}$ \\
\hline 25 & 93.00 & - & 4.430 & $\mathrm{EC}_{100}$ & $\mathrm{EC}_{100}$ \\
\hline 26 & 94.00 & 301 & 4.305 & $\mathrm{EC}_{98}$ & $\mathrm{EC}_{96}$ \\
\hline 27 & 99.20 & 360 & 0.839 & NOEC & NOEC \\
\hline 28 & 94.50 & - & 8.396 & $\mathrm{EC}_{100}$ & $\mathrm{EC}_{100}$ \\
\hline 29 & 92.40 & - & 4.674 & $\mathrm{EC}_{100}$ & $\mathrm{EC}_{100}$ \\
\hline 30 & 96.50 & 335 & 2.050 & $\mathrm{EC}_{44}$ & $\mathrm{EC}_{43}$ \\
\hline
\end{tabular}

respectively and the maximum removal efficiency of diazinon was obtained as 71\% (Kalantary et al. 2014). This difference in the removal of diazinon can be due to the experimental conditions, such as the presence of silica and hydrogen peroxide in the present study.

\section{Table 9 Characteristics of raw water of Seymareh Rive}

\begin{tabular}{ll}
\hline Parameters & Value (average) \\
\hline Temperature $\left({ }^{\circ} \mathrm{C}\right)$ & 16.3 \\
Turbidity $(\mathrm{NTU})$ & 105 \\
Oxygen dissolve $(\mathrm{mg} / \mathrm{L})$ & 6.2 \\
$\mathrm{BOD}(\mathrm{mg} / \mathrm{L})$ & 35 \\
$\mathrm{COD}(\mathrm{mg} / \mathrm{L})$ & 55 \\
Concentration of diazinon $(\mathrm{mg} / \mathrm{L})$ & 1.17 \\
\hline
\end{tabular}

According to the results of this study, four by-products, diazoxon, 7-methyl-3-octyne, 2-isopropyl-6-methyl4-pyrimidinol (IMP) and diethyl phosphonate were identified during degradation of diazinon. By increasing the contact time from 40 to $80 \mathrm{~min}$, the major of by-products were disappeared. Also by determining the toxicity of the effluent from the reactor, it was found that the toxicity of these compounds was less than that of diazinon. Similar to this study (Li et al. 2015), IMP was reported as the oxidation product of diazinon during advanced oxidation process, which is less toxic than its parent compound.

Also, In another study conducted by Kalantary et al. (2014), diazoxon and IMP compounds were introduced as by-products due to the diazinon degradation and by assessing their toxicity, it was found that their toxicity is less than that of diazinon. Therefore, according to the 
results obtained in this study, $\mathrm{Fe}_{3} \mathrm{O}_{4} / \mathrm{SiO}_{2} / \mathrm{TiO}_{2} / \mathrm{H}_{2} \mathrm{O}_{2} /$ UV-C process by producing active radicals $\left(\mathrm{OH}^{*}\right)$ can decompose diazinon and its by-products.

According to the results from Table 8, the degree mineralization of diazinon was determined by using COD experiment. Therefore, the minimum and maximum mineralization of diazinon in effluent reactor was obtained as 88.90 and $99.20 \%$, respectively. By increasing the COD removal percentage, the activity of dehydrogenase enzyme was increased. So, a significant statistical relationship with $P$-value $<0.05$ between COD decomposition and alamar blue reduction was obtained. Based on the results obtained in this study, there was a direct correlation between $\mathrm{ABR}$ and $\mathrm{CFU}$ tests $(\mathrm{P}<0.05)$. Accordingly, $\mathrm{EC}_{50}, \mathrm{EC}_{100}$, and no observed effect concentration in the effluent were obtained as $2.255,4.128$, and $0.890 \mathrm{mg} / \mathrm{L}$, respectively Table 7 . Also, the effluent from the reactor was evaluated with $\mathrm{ABR}$ and CFU tests. According to the results presented in Table 8, $\mathrm{EC}_{50}, \mathrm{EC}_{100}$ and NOEC values for ABR test were obtained as 2.275, 4.430 , and $0.839 \mathrm{mg} / \mathrm{L}$, respectively. By comparing these tests, it can be concluded that, firstly, there is a meaningful relationship between them; secondly, toxicity of the effluent from the reactor and the toxicity of diazinon were confirmed by these new tests. In the study by Toolabi et al. (2017) reducing alamar blue (Resazurin) test of Pseudomonas aerogenousa bacteria was carried out in determining the toxicity of acetamiprid pesticide, In their study, it was found that alamar blue is not only a useful method for toxicity assessment, but it is also a very accurate and simple method.

In the current study, by assessing the toxicity tests on synthetic and real samples were determined, that Environmental factors such as temperature and turbidity is not affected on the performance of Alamar Blue test. In addition to the alamar blue test, the oxidation-reduction potential (ORP) to determine the activity of dehydrogenase enzyme E. coli was performed. Based on the results obtained in Table 8, the number and activity of E. coli bacteria was proportional to the amount of oxidationreduction potential. According to the findings of this section, the alamar blue test was recognized as the most reliable, simplest, new method, rapid and economical for effluent toxicity assessment.

\section{Abbreviations \\ RT: retention time; $A B R$ : alamar blue reduction; COD: chemical oxygen demand; ORP: oxidation reduction potential; NOEC: no observed effect concentration; EC: effective concentration; AOP: advanced oxidation process; GC-MS: gas chromatography Mass; HPLC: high performance liquid chromatography.}

\section{Authors' contributions}

MTG, MM and AT carried out experiments; MT and AT conceived and designed the experiments; $A E$ and MA made a substantial contribution to the analysis and interpretation of the data presented; MHE and AT wrote the paper. MHE, AT, MM and MTG conceived and designed the experiments; AT performed the experiments; AE, MAS and MA made a substantial contribution to the analysis and interpretation of the data presented; MTG wrote the paper. All authors read and approved the final manuscript.

\section{Author details}

${ }^{1}$ Environmental Science and Technology Research Center, Department of Environmental Health Engineering, Shahid Sadoughi University of Medical Sciences, Yazd, Iran. ${ }^{2}$ Environmental Health Engineering Research Center, Kerman University of Medical Sciences, Kerman, Iran. ${ }^{3}$ Department of Environmental Health Engineering, School of Public Health, Kerman University of Medical Sciences, Kerman, Iran. ${ }^{4}$ Department of Environmental Health Engineering, School of Public Health, Iran University of Medical Sciences, Tehran, Iran. ${ }^{5}$ Department of Biostatistics and Epidemiology, Shahid Sadoughi University of Medical Science, Yazd, Iran. ${ }^{6}$ Department of chemistry, Islamic Azad University, Yazd, Iran.

\section{Acknowledgements}

Authors Acknowledge the School of Public Health Bam, for providing the materials and laboratory equipment used in this study.

\section{Competing interests}

The authors declare that they have no competing interests.

Availability of data and materials

Not applicable.

Consent for publication

Not applicable.

\section{Ethics approval and consent to participate}

No human and animals participants were involved in the study.

\section{Funding}

Not applicable.

\section{Publisher's Note}

Springer Nature remains neutral with regard to jurisdictional claims in published maps and institutional affiliations.

Received: 17 February 2018 Accepted: 7 April 2018

Published online: 18 April 2018

\section{References}

Amooey A, Ghasemi S, Mazizi SM, Gholaminezhad Z, Chaich MJ (2014) Removal of diazinon from aqueous solution by electrocoagulation process using aluminum electrodes. Korean J Chem Eng 31(6):1016-1020

Asaithambi P, Alemayehu E, Sajjadi B, Aziz AR (2017) Electrical energy per order determination for the removal pollutant from industrial wastewater using $\mathrm{UV} / \mathrm{Fe}^{2+} / \mathrm{H}_{2} \mathrm{O}_{2}$ process: optimization by response surface methodology. Water Resour Ind 18:17-32

Balouiri M, Sadiki M, Ibnsouda SK (2016) Methods for in vitro evaluating antimicrobial activity: a review. J Pharm Anal 6:71-79

Dehghani M, Shariati Z, Mehrnia MR, Shayeghi M, Ghouti MA, Heibati B, Mckay G, Yetilmezsoy K (2017) Optimizing the removal of organophosphorus pesticide malathion from water using multi-walled carbon nanotubes. Chem Eng J 310:22-32

Ehrampoush MH, Sadeghi A, Ghaneian MT, Bonyadi Z (2017) Optimization of diazinon biodegradation from aqueous solutions by Saccharomyces cerevisiae using response surface methodology. AMB Express 7:1-6

Fadaei A, Deghani M, Mahvi AH, Nasseri S, Rastkari N (2012) Degradation of organophosphorus pesticides in water during UV/H2O2 treatment: role of sulphate and bicarbonate ions. E J Chem 9(4):2015-2022

Gregoraszczuk E, Rmardyła A, Rys J, Jakubowicz J, Urbanski K (2015) Effect of chemotherapeutic drugs on caspase-3 activity, as a key biomarker for 
apoptosis in ovarian tumor cell cultured as monolayer. a pilot study. Iran J Pharm Res 14(4):1153-1161

Gupta V, Eren T, Atar N, Yola ML, Parlak C, Maleh H (2015) $\mathrm{CoFe}_{2} \mathrm{O}_{4} / \mathrm{TiO}_{2}$ decorated reduced grapheneoxide nanocomposites for photocatalytic degradation of chlorpyrifos. Mol Liq 208:122-129

Kalantary R, Shahamat Y, Farzadkia M, Esrafili A, Asgharnia H (2014) Heterogeneous photocatalytic degradation of diazinon in water using nano- TiO2: modeling and intermediates. Eur J Exp Biol 4(1):186-194

Khalifa R, Nasser M, Gomaa AA, Osman NM, Salem HM (2013) Resazurin microtiter assay Plate method for detection of susceptibility of multidrug resistant Mycobacterium tuberculosis to second-line anti-tuberculous drugs. Egypt J Chest Dis Tuberc 62:241-247

Li W, Liu Y, Leeuwen JV, Saint CP (2015) UV and UV/ $\mathrm{H}_{2} \mathrm{O}_{2}$ treatment of diazinon and its influence on disinfection byproduct formation following chlorination. Chem Eng J 274:39-49

Maddah B, Hasanzadeh M (2017) $\mathrm{Fe}_{3} \mathrm{O} / \mathrm{CNT}$ magnetic nanocomposites as adsorbents to remove organophosphorus 4 pesticides from environmental water. Int J Nanosci Nanotechnol 13(2):139-149

Martino M, Sannino F, Pirozzi D (2015) Removal of pesticide from wastewater: contact time optimization for a two-stage batch stirred adsorber. J Environ Chem Eng 3(1):365-372

Mohammadi M, Sabbaghi S (2014) Photo-catalytic degradation of 2,4-DCP wastewater using $\mathrm{MWCNT} / \mathrm{TiO}_{2}$ nano-composite activated by UV and solar light environmental nanotechnology. Monit Manag 2:24-29

Nama S, Cho H, Hanc J, Her N, Yoon J (2018) Photocatalytic degradation of acesulfame K: optimization using the Box-Behnken design (BBD). Process Saf Environ Prot 113:10-21

Nasiry S, Geusens N, Hanssens M, Luyten C, Pijnenborg R (2007) The use of alamar blue assay for quantitative analysis of viability, migration and invasion of choriocarcinoma cells. Hum Reprod 22(5):1304-1309

Pettit R, Pettit G, Weber CA, Rui Tan, Kean MJ, Franks KS, Hoffmann H, Horton ML (2005) Microplate alamar blue assay for Staphylococcus epidermidis biofilm susceptibility testing. Antimicrob Agents Chemother 49(7):2612-2617

Rampersad S (2012) multiple applications of alamar blue as an indicator of metabolic function and cellular health in cell viability bioassays. Sensors 12:12347-12360

Ribeiro A, Nunes O, Pereira MFR, Silva AMT (2015) An overview on the advanced oxidation processes applied for the treatment of water pollutants defined in the recently launched directive 2013/39/EU. Environ Int 75:33-51

Sarrai A, Hanini S, Merzouk NK, Tassalit D, Szabó T, Hernádi K, Nagy L (2016) Using central composite experimental design to optimize the degradation of tylosin from aqueous solution by photo-fenton reaction. Materials 9(428): 1-11

Satyanarayan N, Abaadani W, Shekhar SP, Harishkumar S (2016) Anti-tubercular activity of various solvent extracts of acalypha indica I. against drug susceptible h37rv strain. World J Pharm Pharm Sci 5(8):957-965

Shemer $\mathrm{H}$, Linden K (2006) Degradation and by-product formation of diazinon in water during $\mathrm{UV}$ and $\mathrm{UV} / \mathrm{H}_{2} \mathrm{O}_{2}$ treatment. J Hazard Mater 136(3):553-559

Shunxing L, Wenjie L, Fengying Z, Haifeng Z, Xiaofeng L, Jiabai C (2016) Lysine surface modified $\mathrm{Fe}_{3} \mathrm{O}_{4} / \mathrm{SiO}_{2} / \mathrm{TiO}_{2}$ microspheres-based preconcentration and photocatalysis for in situ selective determination of nanomolar dissolved organic and inorganic phosphorus in seawater. Sens Actuators B Chem 224:48-54

Teh C, Nazni W, Nurulhusna AH, Norazah A, Lee HL (2017) Determination of antibacterial activity and minimum inhibitory concentration of larval extract of fly via resazurin-based turbidometric assay. BMC Microbiol 17:1-8

Tian H, Liu F, He J (2014) Multifunctional $\mathrm{Fe}_{3} \mathrm{O}_{4} / \mathrm{nSiO}_{2} / \mathrm{mSiO}_{2}$-Fe core-shell microspheres for highly efficient removal of 1, 1, 1-trichloro-2, 2-bis (4-chlorophenyl) ethane (DDT) from aqueous media. J Colloid Interface Sci 431:90-96

Toolabi A, Malakootian M, Ghaneian MT, Esrafili A, Ehrampoush MH, Tabatabaei M, AShahi M (2017) Optimization of photochemical decomposition acetamiprid pesticide from aqueous solutions and effluent toxicity assessment by Pseudomonas aeruginosa BCRC using response surface methodology. AMB Express 7:1-12

Tyc O, Menor L, Garbeva P, BCatala E, Micol V (2016) Research article validation of the alamar blue assay as a fast screening method to determine the antimicrobial activity of botanical extracts. PLOS ONE 11(12):1-18

Wang C, Shih Y (2016) Facilitated ultrasonic irradiation in the degradation of diazinon insecticide. Sustain Environ Res 26:110-116

Wang J, Peng L, Cao F, Su B, Shi H (2017) $\mathrm{A} \mathrm{Fe}_{3} \mathrm{O}_{4}-\mathrm{SiO}_{2}-\mathrm{TiO}_{2}$ core-shell nanoparticle: preparation and photocatalytic properties. Inorg Nano-metal Chem 47(3):396-400

Zare MR, Amin M, Nikaeen M, Zare M, Bina B, Fatehizadeh A, Rahmani A, Ghasemian M (2016) Simplification and sensitivity study of alamar blue bioassay for toxicity assessment in liquid media. Desalin Water Treat 57:10934-10940

\section{Submit your manuscript to a SpringerOpen ${ }^{\circ}$ journal and benefit from:}

- Convenient online submission

- Rigorous peer review

- Open access: articles freely available online

- High visibility within the field

Retaining the copyright to your article

Submit your next manuscript at $\boldsymbol{\nabla}$ springeropen.com 